\title{
Melanesia irks Malaysia
}

Malaysia's Primary Industries Minister Datuk Seti Dr Lim Keng Yaik, disturbed by attacks by environmentalists on companies from his country for overlogging, led a two-week forestry mission to PNG, Solomon Islands and Vanuatu in early 1996 to have a first-hand look.

\section{By ALEX CHOONG}

AFTER almost a decade and millions of kina invested in the forestry sector in several South Pacific island nations, the first group of Malaysian timber companies venturing on these islands are now merely 'surviving' or are wrapping up their operations. The going gets tougher by the day - not only with opposition from the environmentalists but also from high govermnment export levies, corporate tax royalties to be paid to landowners increasing social obligations and ever, indirect pressure from the World Bank.

To add insult to an already injured logging operations, the South Pacific Forum adopted the 'Code of Logging Practices' much to the disappointment of logging companies. The code also irked the Minister for Primary Industries Datuk Seri Lim Yaik who spent two weeks visiting Papua New Guinea, Solomon Islands and Vanuatu from March 9 to 24, 1996. He said: 'It appears that such a code simply means logging is a dirty word. I can agree if there is a code for sustainable logging instead.'

Dr Lim, who led a forestry mission, did not mince his words at the end of his tour when he described the situation as 'a mess ... certain Malaysian timber companies have to resort to use good money chasing after bad investments.' Managing director of Rimbunan Hijau Datuk Tiong Hiew King agreed with Dr Lim. Tiong said the world timber industry was now operating in a difficult environment with the continuous environmentalists' criticism on tropical timber.

The company, which came under attack for its logging in Papua New Guinea from the Australian Broadcasting Corporation program, Four Corners, depicted Malaysians as ugly modern pirates who pillage foreign natural re- 


\section{ALEX CHOONG}

sources. The program entitled, 'The Malaysian Invasion,' [The program, made by Deborah Richards, was actually called 'Bush Bugarup'; for full script text see Pacific Journalism Review 1:1 1994, pp 30-36 - Editor] was aired on May 16, 1994, and attacked the company's operations.

Tiong sounded a warning that Malaysian timber companies are now looking towards Brazil and countries in Latin America, as well as African countries, where the cost of acquiring timber concessions is comparatively lower than other tropical timber producing countries. Compounding the already hard-hit operators, countries like Japan have switched from tropical hardwood to temperate hardwood and softwood.

Besides all these problems faced by the timber companies, what further infuriated Dr Lim was the aggressive and competitive manner in which Malaysian companies went about getting land concessions. He said: 'For example, in Vanuatu, it is shocking to find several companies entering into contracts with the same landowners for a similar piece of concession.'

All this, coupled with the banning of log export and the government's insistence that timber companies go downstream, has left the operators in a precarious situation. With changing government policies and uncertainty in the supply of logs, a logging representative in Port Vila, Vanuatu, asked: 'How do you expect us to invest in setting up sawmills which cost millions of ringitt, when we are not even sure of getting enough supply of logs?'

Uncertainty also reigns in these countries, particularly on land ownership and tenure. With so many tribes and clans, it is likely that an individual would appear from nowhere to lay claim and file an injunction against the company for royalties to the trees. A perplexed Dr Lim said: 'It is very difficult to the timber companies to trace each and every person entitled to the land. The government is also not responsible to identify each and every individual.'

To make matters worse, the government handed out large quotas to timber companies to fell trees, without giving a second thought to sustainable forest management policy. However, following pressure from environmentalists and strong influence from the aid-giving Australian government, switched its stand and decided to impose a complete ban on the export of logs. To this Lim says: 'I have conveyed the problems faced by the timber companies to the authorities. If nothing is done to address the situation, the existing government policies would be a deterrent for Malaysian investors to go there.'

The tenacity of political parties in the South Pacific nations have also been a worrying factor for Malaysian investors. Says an official at the Malaysian High Commission in Port Moresby: 'In my three-year stint in Papua New Guinea and observation of the political situation, the tenure of a government hardly last more than 13 months.' 
On the forestry sector, the PNG government plans to impose a 33 per cent timber export levy beginning this month, an increase from 20 per cent in 1993. Malaysian timber companies have to pay a 25 per cent corporate tax and 15 per cent royalties. Several logging operators told Dr Lim during a meeting that most were merely keeping afloat under such conditions.

The minister was also critical of the World Bank and the International Monetary Fund that laid down loan disbursement rules to forest conservation. 'What these international financial institutions are doing is merely to shackle these developing countries to poverty,' he said, adding that they should help and allow these countries to pursue their own course of action.

Dr Lim, who had locked horns with environmentalists, particularly over issues like tropical rainforests, made it clear to these Malaysians' adherence to sustainable management of its rainforest reserves. He said the same could be applied to these developing countries, adding that it was up to the respective governments and the timber companies to work out an amicable solution.

Against the backdrop of the controversial 'Code of Logging Practices', Dr Lim conveyed Malaysia's intension to be a dialogue partner in the South Pacific Forum, where the chairman is PNG Prime Minister, Sir Julius Chan. Having conveyed the message to Sir Julius, Solomon Islands Prime Minister Solomon Mamaloni and Vanuatu Prime Minister Maxime Carlot Korman, Dr Lim said: 'They have all responded positively. I will not push further ... we will wait for their invitation.'

Dr Lim said that if Malaysia participates as a dialogue partner, it will open the channel for the country to explain its role in sustainable forest management and clear any doubts that have been 'finger pointed' on the operation of timber companies in these countries.

Several representatives of timber companies when interviewed appeared to have reached consensus that NGOs from Australia and local environmentalists, who call themselves 'Greenies', have put a lot of pressure on logging activities in these countries. 'It is a case of jealousy,' they said, adding that most of the Malaysian companies that invested in these countries bought the concessions from the Australian-run timber companies.

These Australian-based companies, they said, had failed and now that Malaysians have somewhat turned the company around with proper management and fresh capital injected into the operations. [Australians] have nothing to lose but make things difficult. Despite all this, Dr Lim told government officials from the three nations of the need to reform their laws and other legislation to create a conducive investment climate for foreigners.

To stress his point, he said: 'Almost 40 years ago, Malaysia's economy hinged on tin, and rubber ... similar to the South Pacific nations where the 


\section{ALEX CHOONG}

economy comprises agricultural products.' But Malaysia, he said, did not stop there, but proceeded with its industrialisation program.

'We are moving full gear into high-technology and we will have set a target to achieve a developed nation status by the year 2020,' he said, adding that South Pacific nations should emulate Malaysia as a model. Dr Lim said that of the three nations, the Solomon Islands government had already set the pace. The authorities there were already looking at ASEAN and Asian countries and not to the West, he added.

Dr Lim said the Solomon Islands would set up its High Commission in Kuala Lumpur, which would further pave the way for closer bilateral relations. During the visit, Dr Lim also announced the proposed Solomon IslandsMalaysia Friendship Association. 'This is the start of a new relationship. We will work together for greater economic growth of the two countries.'

In hindsight, while there are still problems to be sorted out, Dr Lim took the opportunity to offer Malaysian-based industries like rubber and palm oil to be located in these South Pacific nations. 'The climate and conditions are right for such a plantation sector,' he said.

Summing up, Dr Lim reminded Malaysian investors that they should be more careful and not make hasty decisions in their investments. "They must also be certain of the project's feasibility before moving in," he added. However, he said the final decision still lay with the investors and a point to ponder, he added, was that these countries were "not money-making centres" unless they made radical changes to land laws and relevant legislation to make it conducive for investors.

Alex Choong is a journalist with the New Straits Times of Malaysia. This article was reprinted in the PNG Post-Courier of 14 May 1996. 